\title{
Supplementary Seleno-L-methionine Suppresses Active Cutaneous Anaphylaxis Reaction
}

\author{
Tomohiro Arakawa, ${ }^{*, a}$ Takeshi Deguchi, ${ }^{a}$ Fumitoshi Sakazaki, ${ }^{b}$ Hirofumi Ogino, ${ }^{a}$ \\ Tomofumi Okuno, ${ }^{a}$ and Hitoshi Ueno ${ }^{a}$ \\ ${ }^{a}$ Department of Public Health \& Preventive Pharmacology, Faculty of Pharmaceutical Sciences, Setsunan University; \\ 45-1 Nagaotoge-cho, Hirakata, Osaka 573-0101, Japan: and ${ }^{b}$ Laboratory of Toxicology, Faculty of Pharmacy, Osaka \\ Ohtani University; 3-11-1 Nishikiori-Kita, Tondabayashi, Osaka 584-8540, Japan.
}

Received July 29, 2013; accepted September 17, 2013

To clarify the relationship between selenium supplementation and type I allergic reaction, we investigated the effect of seleno-L-methionine (SeMet) supplementation on the active cutaneous anaphylaxis (ACA) reaction and cytokine production in splenocytes. Female BALB/c mice were sensitized by intraperitoneal injection of ovalbumin (OVA), and SeMet was administered orally for 2 weeks followed by a challenge with OVA to induce an ACA reaction. SeMet supplementation suppressed the ACA reaction in a dose-dependent manner. Plasma OVA-specific immunoglobulin E (IgE) level was strongly inhibited in SeMet-supplemented mice compared with control mice. The mRNA expression levels of the T helper 2 (Th2) cytokines interleukin (IL)-4 and IL-13 in the spleen of SeMet-supplemented mice were lower than those in control mice. The mRNA expression level of a Th1 cytokine, interferon (IFN)- $\gamma$, in the spleen of SeMet-supplemented mice was higher than that in control mice. Splenocytes restimulated with OVA in vitro from SeMet-supplemented mice produced lower amounts of IL-4 and IL-13 than those of control mice and higher amounts of IFN- $\gamma$ than those from the control mice. These results suggest that oral SeMet supplementation suppresses OVA-induced ACA reaction by lowered Th2 cytokine production and augmenting Th1 cytokine production. phylaxis

Key words seleno-L-methionine; immunoglobulin E; cytokine; T helper 1; T helper 2 ; active cutaneous ana-

Allergic diseases have become a significant health problem, affecting more than $15 \%$ of children and adults worldwide, and their incidence is rising. ${ }^{1,2)}$ Type I allergic diseases, such as atopic dermatitis, asthma and allergic rhinitis, are characterized by an elevated production of the specific immunoglobulin E (IgE) for each antigen. ${ }^{3)}$ Naïve $\mathrm{CD} 4^{+} \mathrm{T}$ cells can differentiate into at least two different types of $\mathrm{T}$ helper (Th) cells, Th1 and Th2., ${ }^{45}$ Th2 cells are characterized by the production of interleukin (IL)-4 and IL-13, which promote the production of IgE. In contrast, Th1 cells are characterized by the production of interferon (IFN)- $\gamma$, which inhibits IgE production and the proliferation of Th2 cells. $^{6-9)}$ It is generally accepted that enhancement of Th2-mediated immunity causes IgE-dependent allergic diseases. Therefore, in the prevention and treatment of type I allergic diseases, it is considered important that the Th2-polarized immune response shifts toward a Th1 phenotype.

Selenium is an essential trace element for mammals and many other forms of life. ${ }^{10)}$ Selenium has been shown to regulate many intracellular functions by being a chemical component of selenoproteins. Well-known selenoproteins include enzymes such as glutathione peroxidase (GPx) and thioredoxin reductase (TR), which have a selenocysteine residue in their catalytic centers and function as critical enzymes in response to oxidative stress. ${ }^{11)}$ The primary dietary selenium sources are wheat ${ }^{12)}$ and yeast, ${ }^{13)}$ which contain seleno-L-methionine (SeMet) and/or selenomethylselenocystine. Many nutritional studies on selenium have been conducted with inorganic selenium compounds, such as sodium selenite and sodium selenate. However, organic selenium compounds, SeMet and selenocystine, have excellent bioavailability and are more ap-

The authors declare no conflict of interest. propriate for nutritional supplementation compared with inorganic selenium compounds. ${ }^{14-17)}$ Moreover, SeMet has lower toxicity compared with various selenium compounds. ${ }^{18-21)}$

Some studies have suggested that patients with type I allergic diseases, such as atopic dermatitis and asthma, had significantly lower selenium concentrations in hair or blood, and significantly lower GPx activity in blood. ${ }^{22-25}$ This has led to speculation that supplementation of selenium compounds might be effective for prevention of type I allergic diseases. Although it has been reported that intraperitoneal (i.p.) injection of sodium selenite in an experimental mouse model of asthma suppresses the activity of nuclear factor (NF)- $\kappa \mathrm{B}$ and inhibits infiltration of eosinophils into lung airway ${ }^{26)}$ it remains unclear whether oral supplementation of SeMet would be beneficial for preventing type I allergic reactions.

In this study, to clarify the relationship between selenium supplementation and type I allergic reactions, we administered SeMet to ovalbumin (OVA)-sensitized mice and investigated the active cutaneous anaphylaxis (ACA) reaction, which is an experimental mouse model of type I allergy. We revealed that SeMet supplementation suppressed the ACA reaction and OVA-specific IgE elevation elicited by repeated OVA injection of mice. We also examined whether SeMet affects the mRNA expression levels of Th2 cytokine IL- 4 and IL-13 and the Th1 cytokine IFN- $\gamma$ in the spleen, and cytokine production of IL-4, IL-13 and IFN- $\gamma$ in splenocytes from OVA-sensitized mice restimulated with OVA in vitro.

\section{MATERIALS AND METHODS}

Animals Female five-week-old BALB/c mice were purchased from Japan SLC Co. (Shizuoka, Japan) and rested for 1 week after arrival. The animals were treated and kept 
in a specific pathogen-free room maintained at $23 \pm 1{ }^{\circ} \mathrm{C}$ and $47-67 \%$ humidity, under a $12 \mathrm{~h}$ light-dark cycle. Mice were given a normal diet (Type CRF-1, Oriental Yeast Co., Tokyo, Japan) throughout the experiment. The experimental protocol satisfied the Animal Experimental Guidelines of Setsunan University, which were modified from the guidelines of the Japanese Society for Pharmacology. This experiment was approved by the Committee for the Ethical Use of Experimental Animals of Setsunan University.

Reagents SeMet was purchased from Acros Organics (Geel, Belgium). OVA (five times crystalized) was purchased from Seikagaku Co. (Tokyo, Japan). Aluminum hydroxide hydrate gel suspension (alum) was purchased from Cosmo Bio, LSL (Tokyo, Japan). Evan's blue was purchased from Tocris Bioscience (MO, U.S.A.).

OVA-Sensitization and Challenge, and SeMet Supplementation On day 0 and day 7, mice were sensitized with i.p. injection of $1 \mu \mathrm{g}$ of OVA and $1 \mathrm{mg}$ of alum dissolved in $0.1 \mathrm{~mL}$ of saline. SeMet (5 or $10 \mu \mathrm{mol} / \mathrm{kg} / \mathrm{d}$ ) or saline was administered orally once daily on days $0-14$. On day 14 , ACA was performed as described by Inagaki et al., ${ }^{27)}$ with a slight modification. In brief, the mice were challenged with $1 \mu \mathrm{g}$ OVA in saline by subcutaneous (s.c.) injection into the ear followed by intravenous (i.v.) injection of $0.25 \mathrm{~mL}$ of $0.5 \%$ Evan's blue solution. Thirty minutes after the challenge, the mice were sacrificed and their ears, plasma and spleen were collected. The ears were used to measure the extravasated dye. Extraction and quantification of the extravasated dye was performed as described by Inagaki et al. ${ }^{28)}$ The amount of dye was measured colorimetrically at $620 \mathrm{~nm}$.

Measurement of Selenium Concentration The plasma $(0.1 \mathrm{~mL})$, liver and spleen tissues $(0.05 \mathrm{~g})$ were digested at $80^{\circ} \mathrm{C}$ for $1 \mathrm{~h}$, then $140^{\circ} \mathrm{C}$ for $2 \mathrm{~h}$ and then $170^{\circ} \mathrm{C}$ for $30 \mathrm{~min}$ in $1 \mathrm{~mL}$ of a 1:2 mixture of nitric acid and perchloric acid. The selenium concentration was measured by the fluorometric method using 2,3-diaminonaphthalene. ${ }^{29)}$

Measurement of OVA-Specific IgE in Plasma OVAspecific IgE in plasma was measured by enzyme-linked immunosorbent assay (ELISA) using a commercially available mouse OVA-specific IgE ELISA Kit (MD Bioproducts, Zürich, Switzerland). The absorbance was measured at $450 \mathrm{~nm}$ using a microplate reader.

Cytokine mRNA Analysis of Spleen Total RNA was extracted from an aliquot of spleen with Sepasol reagent (Nacalai Tesque, Kyoto, Japan) in accordance with the manufacturer's instructions. The concentration and purity of extracted RNA were determined using $A_{260} / A_{280}$ measured on NanoDrop 1000 spectrometer (Thermo Fisher Scientific, MA, U.S.A.). Synthesis of cDNA was conducted using a High Capacity cDNA Reverse Transcription Kit (Applied Biosystems, CA, U.S.A.). The LightCycler 480 System II (Roche Diagnostics GmbH, Mannheim, Germany) was used for realtime quantitative polymerase chain reaction (PCR) analysis.
The oligonucleotides used for quantitative PCR included IL-4 (forward: 5'-TCT CGA ATG TACCAGGAGCCA TAT C-3', reverse: 5'-AGC ACC TTGGAA GCC CTA CAG A-3'), IL-13 (forward: 5'-CCT CTG ACC CTT AAG GAGCTT AT-3', reverse: 5'-CGT TGC ACA GGG GAGTCT-3'), IFN- $\gamma$ (forward: 5'-CGGCAC AGT CAT TGA AAGCCT A-3,' reverse: 5'-GTT GCT GAT GGC CTGATT GTC-3'), Rps18 (forward: 5'-TTC TGGCCA ACG GTC TAG ACA AC-3', reverse: 5'-CCAGTG GTCTTGGTGTGCTGA-3'). Cycling conditions were used as suggested in the SYBR Green Kit instructions, and results were analyzed using Relative Quantification Software (Roche Diagnostics $\mathrm{GmbH}$ ). The results were expressed as mean士 S.D. for the relative expression levels compared with Rps18.

Splenocyte Culture and Cytokine ELISA Splenocytes were prepared by the following method. An aliquot of spleen was gently homogenized and through mesh. After lysis of red blood cells using ammonium chloride hematopoietic buffer, splenocytes were suspended in RPMI medium supplemented with $10 \%$ fetal bovine serum (FBS) and penicillin/streptomycin. The cells were cultured for $72 \mathrm{~h}$ at $37^{\circ} \mathrm{C}, 5 \% \mathrm{CO}_{2}$ in the presence of $100 \mu \mathrm{g} / \mathrm{mL}$ OVA. The cell culture supernatants were stored at $-80^{\circ} \mathrm{C}$ until analysis by ELISA. The amounts of IL-4, IL-13 and IFN- $\gamma$ in the cell culture supernatants were measured by ELISA kits (IL- 4 and IFN- $\gamma$ : BioLegend, CA, U.S.A.; IL-13: eBioscience, CA, U.S.A.), which was performed in accordance with the manufacturer's instructions. Absorbance was measured at $450 \mathrm{~nm}$ using a microplate reader.

Statistical Analysis Statistical significance between two groups was examined using unpaired Student's $t$-test. The symbols $*$ and $* *$ indicate statistical significance at $p$ values of 0.05 and 0.01 in Table and Figs. 1-4, respectively.

\section{RESULTS}

ACA Reaction and OVA-Specific IgE In order to clarify the relationship between selenium supplementation and ACA reaction, SeMet or saline (vehicle control) was administered orally to BALB/c mice with ACA for 2 weeks. Body weight, coat appearance and general grooming were not significantly different between the SeMet-supplemented and control groups (data not shown). As shown in Table 1, the selenium concentration in plasma, liver and spleen was increased by SeMet supplementation in a dose-dependent manner. The effect of SeMet supplementation on type I allergy was measured using the ACA reaction. Assessment of the ACA reaction was done using the amount of extravasated dye, which indicates the permeability of blood vessels at a site of inflammation. As shown in Fig. 1, SeMet supplementation suppressed the amount of extravasated dye in a dose-dependent manner. The amount of extravasated dye in mice administered $5 \mu \mathrm{mol} / \mathrm{kg} / \mathrm{d}$ of SeMet decreased to $67.2 \%$ of that of the control group. In mice administered $10 \mu \mathrm{mol} / \mathrm{kg} / \mathrm{d}$ of SeMet, the amount was suppressed significantly to $38.7 \%$ of that in the control group. Because

Table 1. Selenium Concentration in Plasma, Liver and Spleen

\begin{tabular}{cllc}
\hline \hline SeMet $(\mu \mathrm{mol} / \mathrm{kg} / \mathrm{d})$ & Plasma $(\mathrm{ng} / \mathrm{mL})$ & \multicolumn{1}{c}{ Liver $(\mathrm{ng} / \mathrm{g})$} & Spleen $(\mathrm{ng} / \mathrm{g})$ \\
\hline 0 & $339.06 \pm 15.76$ & $1622.55 \pm 349.58$ & $485.84 \pm 54.02$ \\
5 & $457.86 \pm 83.77^{*}$ & $3376.98 \pm 269.84^{* *}$ & $955.69 \pm 69.49^{* *}$ \\
10 & $528.16 \pm 104.69^{* *}$ & $4937.93 \pm 1291.45^{* *}$ & $1456.15 \pm 276.78^{* *}$ \\
\hline
\end{tabular}

The results are presented as mean \pm S.D. $(n=10) . * * p<0.01, * p<0.05$ compared with control. 


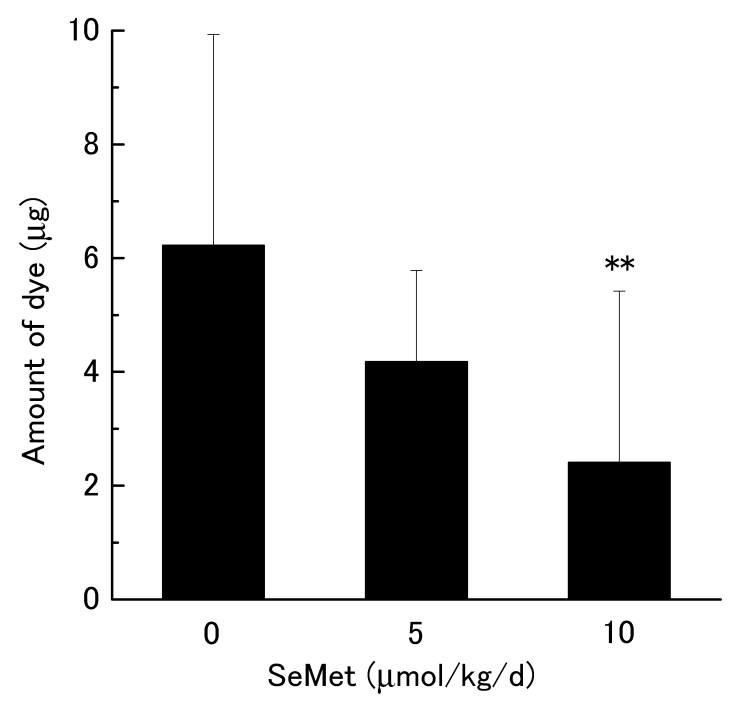

Fig. 1. Effect of SeMet Supplementation on the ACA Reaction

Mice were supplemented with SeMet for 2 weeks and sensitized with OVA/alum by i.p. injection twice. On the final day, the mice were challenged with OVA by s.c. injection into the ear followed by i.v. injection of Evan's blue solution. The amount of extravasated dye was measured colorimetrically at $620 \mathrm{~nm}$. The results are presented as mean \pm S.D. $(n=15) .{ }^{* *} p<0.01$ compared with control.

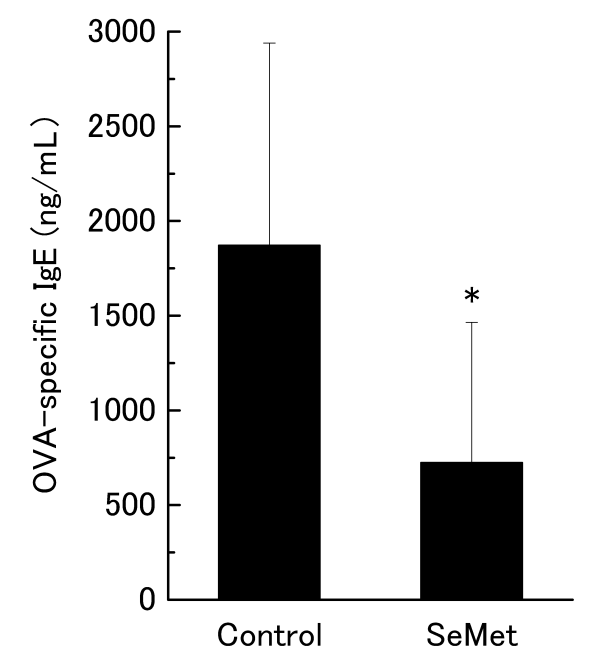

Fig. 2. Effect of SeMet Supplementation on OVA-Specific IgE in Plasma

Mouse plasma was obtained from each mouse and the OVA-specific IgE level was determined by ELISA. The results are presented as mean \pm S.D. $(n=10)$. $* p<0.05$ compared with control.

the ACA reaction was suppressed significantly at a dose of $10 \mu \mathrm{mol} / \mathrm{kg} / \mathrm{d}$, we focused on this for subsequent experiments.

The production of antigen-specific IgE is a crucial component of type I allergy. Plasma was collected at $30 \mathrm{~min}$ after the challenge and measured by ELISA. As shown in Fig. 2, the OVA-specific IgE level in plasma was strongly inhibited to $38.6 \%$ in SeMet-supplemented mice, compared with the control group.

Th1 and Th2 Cytokines in Splenocytes In type I allergy, the immune response is polarized to a Th2 phenotype. To examine the effect of SeMet supplementation on $\mathrm{CD}^{+} \mathrm{T}$ cell differentiation, spleen was collected at $30 \mathrm{~min}$ after the challenge and total RNA was extracted. The mRNA expression levels of IL-4 and IL-13 (Th2 cytokines) and IFN- $\gamma$ (Th1 cytokine) were measured using real-time quantitative PCR. As shown in Figs. 3A and B, the mRNA expression levels of IL-4 and IL-13 were significantly lower in SeMet-supplemented mice. Conversely, the mRNA expression level of IFN- $\gamma$ was significantly higher in SeMet-supplemented mice (Fig. 3C). The mRNA expression levels of IL-4 and IL-13 in unsensitized mice were significantly low compared with the OVAsensitized control mice (Figs. 3A, B). The mRNA expression level of IFN $-\gamma$ in unsensitized mice was the same level of the OVA-sensitized control mice (Fig. 3C).

To examine the cytokine production ability of splenocytes from SeMet-supplemented mice, splenocytes was collected at $30 \mathrm{~min}$ after the challenge and cultured for $72 \mathrm{~h}$ with OVA in vitro. As shown in Fig. 4A, the splenocytes from OVAsensitized, SeMet-supplemented mice restimulated with OVA released significantly lower levels of IL-4 in mice compared those from control mice. IL-13 produced by the splenocytes of the SeMet-supplemented mice was likely to be lower than that in the control (Fig. 4B). However, the level of IFN- $\gamma$ produced by the splenocytes was significantly higher in SeMet-supplemented mice compared with the control (Fig. 4C).

\section{DISCUSSION}

Patients with type I allergic diseases, such as atopic dermatitis and asthma, show significantly lower selenium concentrations in hair or blood. ${ }^{22-25)}$ This had led to speculation that supplementation of selenium compounds might be effective to prevent type I allergic diseases. It has been reported that i.p. injection of sodium selenite in an experimental mouse model of asthma suppresses the activity of NF- $\kappa \mathrm{B}$ and inhibits infiltration of eosinophils into lung airway. ${ }^{26)}$ However, it remains unclear whether oral supplementation of SeMet would be beneficial for preventing type I allergic reactions. Furthermore, the effect of SeMet supplementation on the production of Th1 and Th2 cytokines in splenocytes is not known. In this study, we showed that oral SeMet supplementation suppressed the OVA-induced ACA reaction by lowering Th2 cytokine production and augmenting Th1 cytokine production.

In the present study, $5 \mu \mathrm{mol} / \mathrm{kg} / \mathrm{d}$ of SeMet administered to mice tended to decrease the ACA reaction compared with the control group. In mice receiving $10 \mu \mathrm{mol} / \mathrm{kg} / \mathrm{d}$ of SeMet exhibited a significantly suppressed ACA reaction. The suppression level of the ACA reaction by SeMet supplementation was dose-dependent.

Type I allergic diseases, such as atopic dermatitis and asthma, are characterized by the elevated production of an antigen-specific IgE. ${ }^{3)}$ In this study, OVA-specific IgE level in the plasma of SeMet-supplementated mice was significantly lower than in mice in the control group. These results suggest that SeMet supplementation affects the production of antigenspecific IgE. Secretion of $\operatorname{IgE}$ is induced by the activation of Th2 cells, and the activation of Th2 cells is regulated by Th1 cells. ${ }^{6-9)}$ Sensitization by intraperitoneal injection of OVA and alum shifts the Th1/Th2 response toward Th2. Therefore, attempts to exaggerate the Th1 response are important for such Th2-biased immune reactions to restore Th1/Th2 balance. To assess the effect of SeMet on $\mathrm{CD}^{+}{ }^{+} \mathrm{T}$ cell differentiation, total RNA was extracted from the spleen, and the mRNA expression levels of Th2 cytokines (IL-4, IL-13) and a Th1 cytokine $(\mathrm{IFN}-\gamma)$ were measured. The IL-4 and IL-13 mRNA expression levels were significantly lower in mice receiving SeMet supplementation than in control mice. Conversely, the mRNA 
A

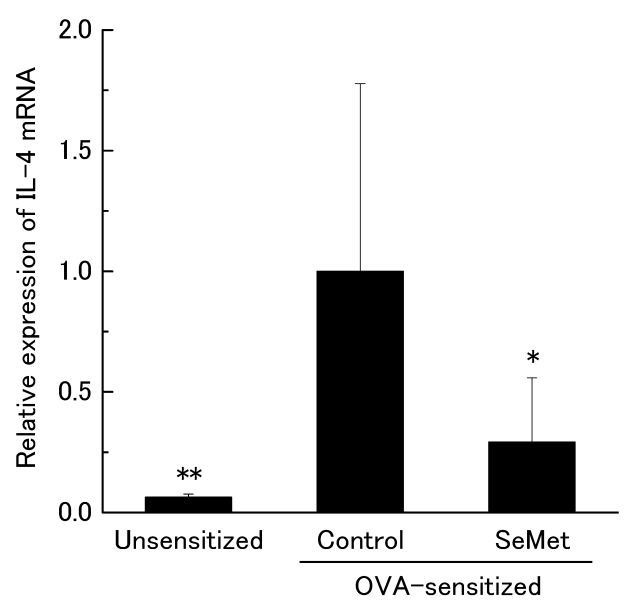

C

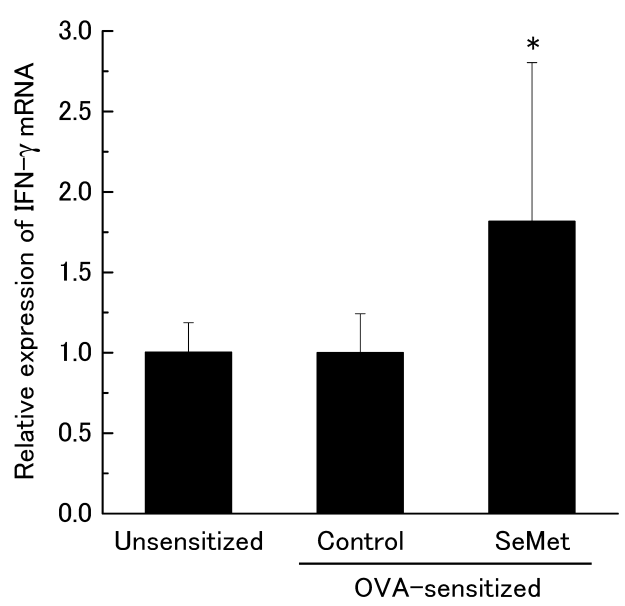

B

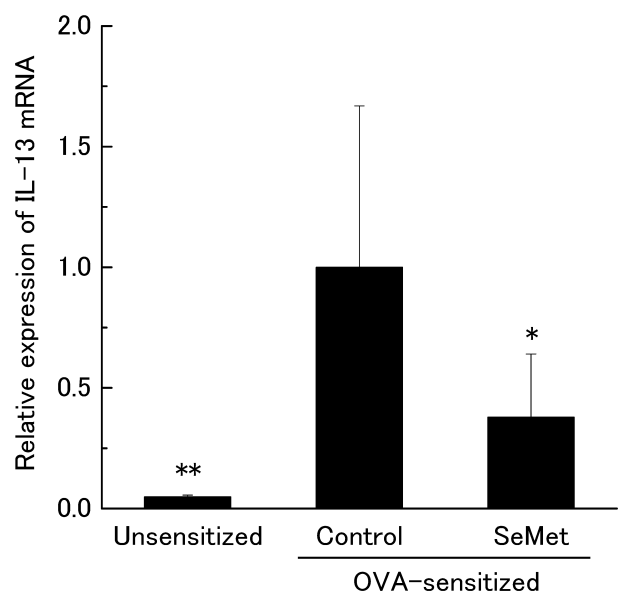

Fig. 3. Effect of SeMet Supplementation on Cytokine mRNA Expression Levels in the Spleen

Total RNA was extracted from the spleen, and IL-4 (A), IL-13 (B) and IFN- $\gamma$ (C) mRNA expression levels were determined by real-time quantitative PCR. The results are presented as mean \pm S.D. $(n=10)$ for the relative expression levels compared with Rps18. ${ }^{* *} p<0.01,{ }^{*} p<0.05$ compared with control.

A

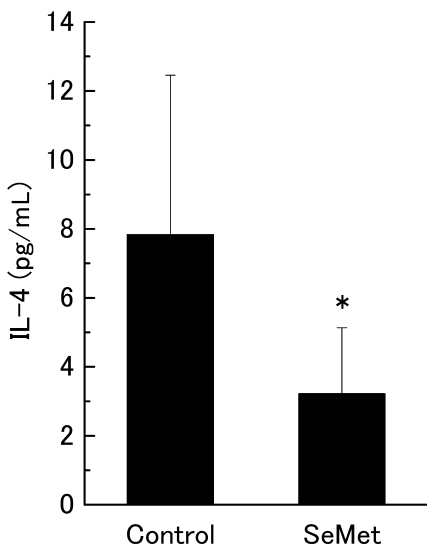

B

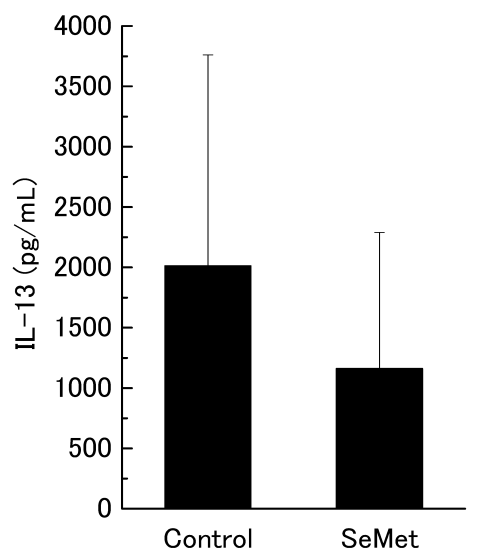

C

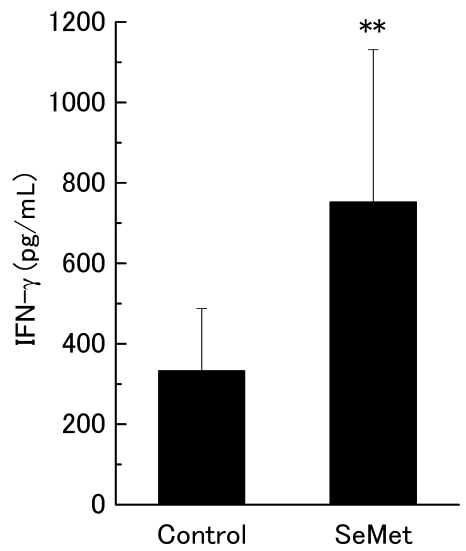

Fig. 4. Effect of SeMet Supplementation on Cytokine Production in Splenocytes Restimulated with OVA in Vitro

Splenocytes were cultured with OVA for $72 \mathrm{~h}$, the supernatants were collected and production levels of IL-4 (A), IL-13 (B) and IFN- $\gamma$ (C) were determined by ELISA. The results are presented as mean \pm S.D. $(n=10) . * * p<0.01, * p<0.05$ compared with control.

expression of IFN- $\gamma$ was significantly higher in mice receiving SeMet supplementation than in control mice.

It has been reported that there is little production of IL-4, IL-13 and IFN- $\gamma$ by splenocytes from OVA-sensitized mice cultured for $72 \mathrm{~h}$ without OVA. ${ }^{30,31)}$ Therefore, we investigated the effect of SeMet on the production of IL-4, IL-13 and IFN- $\gamma$ by splenocytes from OVA-sensitized mice cultured for $72 \mathrm{~h}$ with OVA in vitro. Splenocytes from the SeMet- 
supplemented group exhibited a significantly lower production of IL-4 than those from the control group. Similarly, IL-13 production showed a tendency to decrease in splenocytes from the SeMet-supplemented group compared with those from the control group. IFN- $\gamma$ production in splenocytes from the SeMet-supplemented group increased significantly compared with those from the control group. Cytokine production in splenocytes restimulated with OVA in vitro correlated with the cytokine mRNA expression levels in the spleen. Elser et al. reported that IFN- $\gamma$ suppresses IL-4 expression levels at the transcriptional level via the repression of IL-4 promoter activity by IFN- $\gamma$-inducible factors IRF-1 and IRF-2. ${ }^{32)}$ These findings suggest that SeMet supplementation might regulate the expression of IL-4 and IFN- $\gamma$ at the transcriptional level.

It has been reported that plasma selenium concentration is useful in monitoring compliance of selenium supplementation with SeMet. ${ }^{15)}$ We measured plasma selenium concentrations of SeMet-supplemented and control mice. The selenium level in the plasma of mice supplemented with 5 or $10 \mu \mathrm{mol} / \mathrm{kg} / \mathrm{d}$ SeMet increased 1.3-fold and 1.6-fold compared with control mice, respectively. The selenium content in the liver and spleen was also increased by SeMet supplementation in a dose-dependent manner. Absorbed selenium is used for the synthesis of selenoproteins such as GPx, TR and selenoprotein S (SelS). GPx and TR are anti-oxidant enzymes and their activities are significantly increased in mice or rats fed high supplemental level of selenium containing diet compared with mice or rats fed normal level of selenium containing diet. ${ }^{33-35)}$ Recently, it was reported that increasing GPx and TR activities alter the immune response toward a Th1 phenotype. ${ }^{36)}$ SelS is also considered to regulate the immune response and redox balance. ${ }^{37,38)}$ These findings suggest that SeMet supplementation might optimize Th1 and Th2 cytokine expression by regulation of redox balance through increased production of selenoproteins.

In the present study, SeMet or saline was administered orally to BALB/c mice for 2 weeks. There were no significant differences in food consumption between control group and SeMet-supplemented group (data not shown). According to the manufacturer's data, selenium concentration in the diet was $0.42 \mathrm{ppm}$. Therefore, in this study, each mouse received an average of $1.0 \mu \mathrm{g} / \mathrm{d}$ of selenium from normal diet. The mean values of selenium intake by oral administration of SeMet were $7.4 \mu \mathrm{g}$ selenium $/ \mathrm{mouse} / \mathrm{d}$ for $5 \mu \mathrm{mol} / \mathrm{kg} / \mathrm{d}$ of SeMet-supplemented group, and $14.9 \mu \mathrm{g}$ selenium/mouse $/ \mathrm{d}$ for $10 \mu \mathrm{mol} /$ $\mathrm{kg} / \mathrm{d}$ of SeMet-supplemented group. It has been reported that oral administration of SeMet at $0.2 \mathrm{mg} / \mathrm{mouse} / \mathrm{d}(80.5 \mu \mathrm{g}$ selenium/mouse/d) for $28 \mathrm{~d}$ is safe and nontoxic for mice. ${ }^{39)}$ Therefore, the administration dose in this study is considered to be safe and nontoxic for mice. The U.S. Food and Nutrition Board at the Institute of Medicine set the recommended daily allowance (RDA) of selenium at $55 \mu \mathrm{g} / \mathrm{d}$ for adult human. ${ }^{40)}$ The dietary requirement of selenium for mice is $0.4 \mu \mathrm{g} / \mathrm{d}$, according to the National Research Council. ${ }^{41)}$ The daily requirement of selenium for human is much lower than mice, further studies are required for clinical application.

In conclusion, we have shown that oral SeMet supplementation suppressed OVA-induced ACA reaction in mice, which is mediated by inhibition of OVA-specific IgE elevation elicited by repeated OVA injection, a decrease in Th2 cytokines (IL-4, IL-13) production, and the augmentation of Th1 cytokine
$(\mathrm{IFN}-\gamma)$ production.

Acknowledgments The authors thank Ms. Aoi Fujita, Mr. Yuki Hirota, Ms. Yurie Yoshii, Ms. Shizuka Nakayama, Ms. Airi Minamide and Ms. Mariko Tatsu for excellent technical assistance.

\section{REFERENCES}

1) Arshad SH. Primary prevention of asthma and allergy. J. Allergy Clin. Immunol., 116, 3-14, quiz, 15 (2005).

2) Bieber T. Atopic dermatitis. N. Engl. J. Med., 358, 1483-1494 (2008).

3) Platts-Mills TA. The role of immunoglobulin E in allergy and asthma. Am. J. Respir. Crit. Care Med., 164 (Suppl. 1), S1-S5 (2001).

4) Mowen KA, Glimcher LH. Signaling pathways in Th2 development. Immunol. Rev., 202, 203-222 (2004).

5) Murphy KM, Reiner SL. The lineage decisions of helper T cells. Nat. Rev. Immunol., 2, 933-944 (2002).

6) Coffman RL, Ohara J, Bond MW, Carty J, Zlotnik A, Paul WE. B cell stimulatory factor-1 enhances the IgE response of lipopolysaccharide-activated B cells. J. Immunol., 136, 4538-4541 (1986).

7) Pène J, Rousset F, Brière F, Chrétien I, Bonnefoy JY, Spits H, Yokota T, Arai N, Arai K, Banchereau J, de Vries JE. IgE production by normal human lymphocytes is induced by interleukin 4 and suppressed by interferons gamma and alpha and prostaglandin E2. Proc. Natl. Acad. Sci. U.S.A., 85, 6880-6884 (1988).

8) Sher A, Coffman RL. Regulation of immunity to parasites by $\mathrm{T}$ cells and T cell-derived cytokines. Annu. Rev. Immunol., 10, 385409 (1992).

9) Fitch FW, McKisic MD, Lancki DW, Gajewski TF. Differential regulation of murine T lymphocyte subsets. Annu. Rev. Immunol., 11, 29-48 (1993).

10) Rayman MP. The importance of selenium to human health. Lancet, 356, 233-241 (2000).

11) Allan CB, Lacourciere GM, Stadtman TC. Responsiveness of selenoproteins to dietary selenium. Annu. Rev. Nutr., 19, 1-16 (1999).

12) Wolf WR, Zainal H. Methylseleno-amino acid content of food materials by stable isotope dilution mass spectrometry. Food Nutr. Bull., 23 (Suppl), 120-123 (2002).

13) McSheehy S, Yang L, Sturgeon R, Mester Z. Determination of methionine and selenomethionine in selenium-enriched yeast by species-specific isotope dilution with liquid chromatography-mass spectrometry and inductively coupled plasma mass spectrometry detection. Anal. Chem., 77, 344-349 (2005).

14) Tiwary AK, Stegelmeier BL, Panter KE, James LF, Hall JO. Comparative toxicosis of sodium selenite and selenomethionine in lambs. J. Vet. Diagn. Invest., 18, 61-70 (2006).

15) Burk RF, Norsworthy BK, Hill KE, Motley AK, Byrne DW. Effects of chemical form of selenium on plasma biomarkers in a high-dose human supplementation trial. Cancer Epidemiol. Biomarkers Prev., 15, 804-810 (2006).

16) Fairweather-Tait SJ. Bioavailability of selenium. Eur. J. Clin. Nutr., 51 (Suppl 1), S20-S23 (1997).

17) Rayman MP. The use of high-selenium yeast to raise selenium status: how does it measure up? Br. J. Nutr., 92, 557-573 (2004).

18) Griffiths NM, Stewart RD, Robinson MF. The metabolism of [75Se] selenomethionine in four women. Br. J. Nutr., 35, 373-382 (1976).

19) Schrauzer GN. Selenomethionine: a review of its nutritional significance, metabolism and toxicity. J. Nutr., 130, 1653-1656 (2000).

20) Schrauzer GN. The nutritional significance, metabolism and toxicology of selenomethionine. Adv. Food Nutr. Res., 47, 73-112 (2003).

21) Hoefig CS, Renko K, Kohrle J, Birringer M, Schomburg L. Comparison of different selenocompounds with respect to nutritional value $v s$. toxicity using liver cells in culture. J. Nutr. Biochem., 22, 945-955 (2011). 
22) Yamada T, Saunders T, Kuroda S, Sera K, Nakamura T, Takatsuji T, Hara T, Nose Y, Fukuoka College of Obstetricians and Gynecologists, Pediatric Association of Fukuoka District. Cohort study for prevention of atopic dermatitis using hair mineral contents. J. Trace Elem. Med. Biol., 27, 126-131 (2013).

23) Kadrabová J, Mad'aric A, Kovaciková Z, Podivínsky F, Ginter E, Gazdík F. Selenium status is decreased in patients with intrinsic asthma. Biol. Trace Elem. Res., 52, 241-248 (1996).

24) Misso NL, Powers KA, Gillon RL, Stewart GA, Thompson PJ. Reduced platelet glutathione peroxidase activity and serum selenium concentration in atopic asthmatic patients. Clin. Exp. Allergy, 26, 838-847 (1996).

25) Qujeq D, Hidari B, Bijani K, Shirdel H. Glutathione peroxidase activity and serum selenium concentration in intrinsic asthmatic patients. Clin. Chem. Lab. Med., 41, 200-202 (2003).

26) Jeong DW, Yoo MH, Kim TS, Kim JH, Kim IY. Protection of mice from allergen-induced asthma by selenite: prevention of eosinophil infiltration by inhibition of NF-kappa B activation. J. Biol. Chem., 277, 17871-17876 (2002).

27) Inagaki N, Miura T, Nagai H, Koda A. Active cutaneous anaphylaxis (ACA) in the mouse ear. Jpn. J. Pharmacol., 59, 201-208 (1992).

28) Inagaki $\mathrm{N}$, Goto $\mathrm{S}$, Nagai H, Koda A. Mouse ear PCA as a model for evaluating antianaphylactic agents. Int. Arch. Allergy Appl. Immunol., 74, 91-92 (1984).

29) Watkinson JH. Fluorometric determination of selenium in biological material with 2,3-diaminonaphthalene. Anal. Chem., 38, 92-97 (1966).

30) Kashiwada M, Cassel SL, Colgan JD, Rothman PB. NFIL3/E4BP4 controls type $2 \mathrm{~T}$ helper cell cytokine expression. EMBO J., 30, 2071-2082 (2011).

31) Morokata $T$, Ishikawa J, Ida $K$, Yamada $T$. C57BL/6 mice are more susceptible to antigen-induced pulmonary eosinophilia than BALB/c mice, irrespective of systemic $\mathrm{T}$ helper 1/T helper 2 responses. Immunology, 98, 345-351 (1999).

32) Elser B, Lohoff M, Kock S, Giaisi M, Kirchhoff S, Krammer PH, Li-Weber M. IFN-gamma represses IL-4 expression via IRF-1 and IRF-2. Immunity, 17, 703-712 (2002).

33) Zeng MS, Li X, Liu Y, Zhao H, Zhou JC, Li K, Huang JQ, Sun LH, Tang JY, Xia XJ, Wang KN, Lei XG. A high-selenium diet induces insulin resistance in gestating rats and their offspring. Free Radic. Biol. Med., 52, 1335-1342 (2012).

34) Kim JH, Hue JJ, Kang BS, Park H, Nam SY, Yun YW, Kim JS, Lee BJ. Effects of selenium on colon carcinogenesis induced by azoxymethane and dextran sodium sulfate in mouse model with high-iron diet. Lab. Anim. Res., 27, 9-18 (2011).

35) Lai IK, Chai Y, Simmons D, Watson WH, Tan R, Haschek WM, Wang K, Wang B, Ludewig G, Robertson LW. Dietary selenium as a modulator of PCB 126-induced hepatotoxicity in male SpragueDawley rats. Toxicol. Sci., 124, 202-214 (2011).

36) Hoffmann FW, Hashimoto AC, Shafer LA, Dow S, Berry MJ, Hoffmann PR. Dietary selenium modulates activation and differentiation of CD4+ $\mathrm{T}$ cells in mice through a mechanism involving cellular free thiols. J. Nutr., 140, 1155-1161 (2010).

37) Curran JE, Jowett JB, Elliott KS, Gao Y, Gluschenko K, Wang J, Abel Azim DM, Cai G, Mahaney MC, Comuzzie AG, Dyer TD, Walder KR, Zimmet P, MacCluer JW, Collier GR, Kissebah AH, Blangero J. Genetic variation in selenoprotein $\mathrm{S}$ influences inflammatory response. Nat. Genet., 37, 1234-1241 (2005).

38) Goldson AJ, Fairweather-Tait SJ, Armah CN, Bao Y, Broadley MR, Dainty JR, Furniss C, Hart DJ, Teucher B, Hurst R. Effects of selenium supplementation on selenoprotein gene expression and response to influenza vaccine challenge: a randomised controlled trial. PLoS ONE, 6, e14771 (2011).

39) Cao S, Durrani FA, Rustum YM. Selective modulation of the therapeutic efficacy of anticancer drugs by selenium containing compounds against human tumor xenografts. Clin. Cancer Res., 10, 2561-2569 (2004).

40) Panel on Dietary Antioxidants and Related Compounds. Subcommittees on Upper Reference Levels of Nutrients and Interpretation and Uses of DRIs, Standing Committee on the Scientific Evaluation of Dietary Reference Intakes, Food and Nutrition Board, Institute of Medicine. Dietary Reference Intakes for Vitamin C, Vitamin E, Selenium, and Carotenoids. The National Academies Press, Washington, D.C. (2000).

41) Subcommittee on Laboratory Animal Nutrition. Committee on Animal Nutrition, Board on Agriculture, National Research Council. Nutrient Requirements of Laboratory Animals. The National Academies Press, Washington, D.C. (1995). 